\title{
Influence of technology elements on the yield and grain quality of spring wheat in the northern forest- steppe of the Tyumen region
}

\author{
Yury Loginov ${ }^{1}$, Anastasia Kazak $^{1, *}$, Lyudmila Yakubyshina $^{1}$, and Sergey Yashchenko ${ }^{1}$ \\ Northern Trans-Ural State Agricultural University, Republiki Str., 7, 625003 Tyumen Region, Tyumen, \\ Russia
}

\begin{abstract}
It was found that varieties Novosibirskaya 31 and Iren have an advantage in yield and grain quality over Omskaya 36 and Tyumenskaya 25 in terms of the predecessors of annual grasses and green manure fallow. For varieties Omskaya 36, Tyumenskaya 25, Iren, the background of mineral nutrition is optimal for obtaining a yield of $4 \mathrm{t} / \mathrm{ha}$. A further increase in yield leads to a decrease in grain quality. The exception was the Novosibirskaya 31 variety, which retained the grain quality to a yield level close to $5 \mathrm{t} / \mathrm{ha}$. The best sowing dates are the first and second.
\end{abstract}

\section{Introduction}

The Tyumen region mainly provides itself with wheat grain, but in the future, solving this problem, especially improving the quality of grain, may be problematic [1-3]. One of the reasons for this is the violation of one-man management in the selection-variety-testing-production system. Spring wheat breeding is carried out in scientific and educational institutions by fallow, in the system of the State variety testing, varieties are studied by fallow and grain predecessor and under production conditions, and spring wheat is sown in small quantities in pairs [4-5]. At the state variety plots for the grain predecessor, the yield of wheat varieties is 1.5-2 times higher than in production. The fact is that during the period from 1937 to the present, the variety testing plots, using high doses of mineral fertilizers, performing qualitatively the elements of technology and other agricultural activities significantly increased the fertility of their fields [6-8]. They keep all this even during the years of perestroika.

Many ordinary farms in the region, which make up about $70 \%$ of the total, on the contrary, reduced the application of mineral and organic fertilizers, reduced the percentage of fallow in crop rotations to a minimum (4-5\% instead of $15-20 \%)$ [9-11]. It should be noted that the role of steam in the crop rotation of the Tyumen region is unjustifiably underestimated. Crop rotations are up to $70 \%$ saturated with grain crops, which does not contribute to an increase in soil fertility. It is necessary to have more steam, legumes and other crops in the crop rotation.

Another of the reserves for increasing the yield and grain quality of spring wheat is the cultivar [12-13]. It should be noted that in recent decades, breeders of Western Siberia and the

\footnotetext{
${ }^{*}$ Corresponding author: kazaknastenka@rambler.ru
} 
Urals have created a series of varieties of valuable and strong wheat, but under production conditions they are cultivated according to generally accepted technology, therefore they do not realize their potential $[6,14]$.

Objective of the research: to study the influence of predecessors, sowing dates and backgrounds of mineral nutrition on the yield and grain quality of spring wheat varieties in the northern forest-steppe of the Tyumen region.

The tasks of the research were to study the duration of the growing season, resistance to lodging and diseases, yield, grain quality.

\section{Material and methods}

The studies were carried out in 2016-2018 on the experimental field of the SAU of the Northern Trans-Urals, in the northern forest-steppe of the Tyumen region. The soil is leached chernozem, heavy loamy in granulometric composition, the content of nitrogen and phosphorus is medium, potassium is high, the humus content is $7.2 \%$, the reaction of the soil solution is 6.7 . The predecessor is green manure fallow, annual grasses and cereals. The processing is common for the culture in the zone [15]. Mineral fertilizers were applied according to the predecessor annual grasses for the planned yield of $3 ; 4 ; 5$ t/ha.

The object of the study was taken from the registered varieties of spring wheat, which are widespread in the Tyumen region Iren, Omskaya 36, Tyumenskaya 25. The standard is the Novosibirskaya 31 variety, which occupies the maximum sowing area compared to other varieties.

Three sowing terms were studied: the first at a soil temperature of $+8+10 \circ \mathrm{C}$, the second after 10 days, the third - 20 days after the first. The area of the plot is $60 \mathrm{~m}^{2}$, the counting area is $50 \mathrm{~m}^{2}$, the replication is 4-fold, the placement of the plots is systematic. Sowing was carried out with a SSFK-10 seeder, harvesting with a Sampo 130 combine.

Observations and counts were carried out according to generally accepted methods. Crop data were processed statistically using Microsoft Excel 2010 software.

\section{Rezults and discussion}

Years of weather research have been favorable for the growth, development of plants and the formation of wheat grain yields. In conditions of risky agriculture, early maturity of wheat varieties is given special importance $[6,16]$. The varieties studied by us belong to the early maturing group. For green manure fallow and annual grasses with different levels of mineral nutrition, the maximum duration of the growing season was in the varieties Novosibirskaya 31, Iren - 97-99 days, in Omskaya 36 and Tyumenskaya 25 - 104-106 days, which is quite acceptable for the northern forest-steppe of the Tyumen region. For annual grasses without the use of mineral fertilizers, the growing season for wheat varieties decreased by 5-7 days, and for grain predecessors - by 9-11 days.

The disadvantage of most varieties of spring wheat in the Tyumen region is low resistance to brown leaf and stem rust, as well as in some years - to septoria and powdery mildew. Diseases annually take $25-30 \%$ of the harvest $[12,17]$. Over the years of research, cultivar Omskaya 36 showed low resistance to leaf rust (3 points), and cultivar Tyumenskaya 25 showed low resistance to septoria (3 points). Varieties Novosibirskaya 31 and Iren showed medium and high resistance to the noted and other diseases.

In the second half of the 20th - at the beginning of the 21 st centuries, Siberian breeders quite successfully solve the problem of resistance of wheat varieties to lodging, although many varieties still lodge against a high nutritional background [7]. Our assessment in the experiment 
with different levels of mineral nutrition, as well as green manure fallow, showed high resistance to lodging of varieties Novosibirskaya 31, Iren and Tyumenskaya 25 with a yield of $4 \mathrm{t} /$ ha. Variety Omskaya 36, with the observed yield, fell heavily. With a yield of more than $4 \mathrm{t} / \mathrm{ha}$, the varieties noted above showed a tendency to lodging, but they could be harvested with combines.

The main indicator in studying the reaction of wheat varieties to elements of cultivation technology is yield (Fiq. 1).

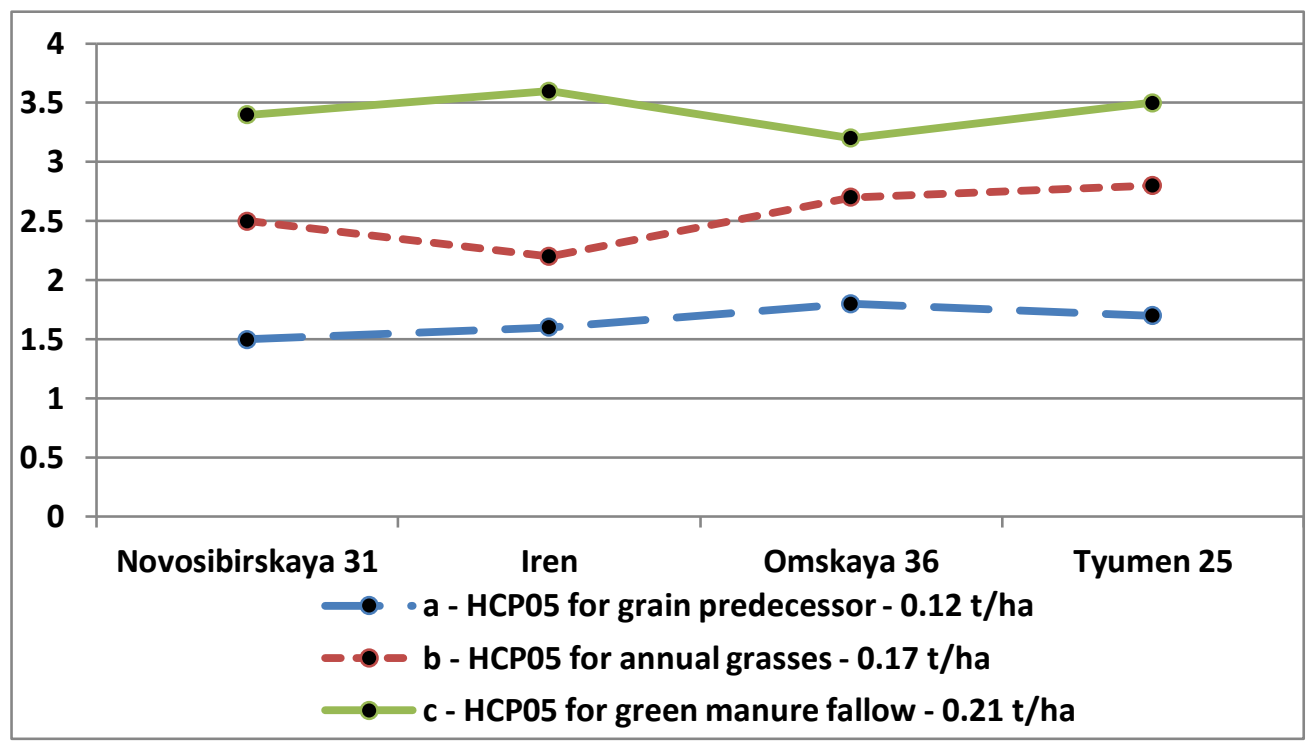

Fiq. 1. Productivity of wheat varieties by different predecessors, 2016-2018

For the grain predecessor, the Omskaya 36 variety stood out with a yield of $1.89 \mathrm{t} / \mathrm{ha}$, which is $0.31-0.44 \mathrm{t} / \mathrm{ha}$ higher than the standard Novosibirskaya 31 and other studied varieties.

Annual grasses are widely used in the Tyumen region as a precursor for spring wheat. From the data in Figure 1, it can be seen that for the noted predecessor, the yield is higher than for grain by $0.56-0.93 \mathrm{t} / \mathrm{ha}$. At the same time, the maximum yield $-2.69-2.75 \mathrm{t} / \mathrm{ha}$ was given by the varieties Omskaya 36 and Tyumenskaya 25.

The best predecessor in the experiment was green manure fallow from rapeseed. The yield of wheat varieties for this predecessor varied from $3.32 \mathrm{t} / \mathrm{ha}$ for the Omskaya 36 variety to 3.65 $\mathrm{t} / \mathrm{ha}$ for the Iren variety.

In market conditions, it is important that the yield is combined with the quality of the grain $[17,18]$. Long-term agronomic practice has shown that obtaining high quality grain is a more difficult task than increasing the yield. The grain quality is influenced by many factors, including the predecessor (table 1).

Table 1. Grain quality of wheat varieties depending on the predecessor, 2016-2018

\begin{tabular}{|c|c|c|c|c|c|c|}
\hline \multirow[b]{2}{*}{ № } & \multirow[b]{2}{*}{ Variety } & \multirow[b]{2}{*}{ Predecessor } & \multirow{2}{*}{$\begin{array}{l}\text { Volumetric } \\
\text { weight of } \\
\text { grain, g/l }\end{array}$} & \multicolumn{2}{|c|}{ Content, \% } & \multirow{2}{*}{$\begin{array}{c}\text { Gluten } \\
\text { quality, } \\
\text { units IDK-1 }\end{array}$} \\
\hline & & & & protein & $\begin{array}{l}\text { gluten } \\
\text { free }\end{array}$ & \\
\hline \multirow[t]{3}{*}{1.} & \multirow{3}{*}{$\begin{array}{l}\text { Novosibirskaya } \\
\text { 31, standard }\end{array}$} & green manure & 795 & 16.9 & 30.7 & $54-62$ \\
\hline & & annual herbs & 778 & 15.4 & 27.5 & $48-70$ \\
\hline & & cereals & 732 & 13.2 & 24.3 & $81-95$ \\
\hline \multirow[t]{2}{*}{2.} & \multirow[t]{2}{*}{ Iren } & green manure & 807 & 15.7 & 29.8 & $49-68$ \\
\hline & & annual herbs & 763 & 14.5 & 26.4 & $60-74$ \\
\hline
\end{tabular}




\begin{tabular}{|l|l|l|c|c|c|c|}
\hline & & cereals & 719 & 12.3 & 22.1 & $87-105$ \\
\hline \multirow{3}{*}{3.} & Omskya 36 & green manure & 804 & 16.1 & 27.9 & $67-73$ \\
\cline { 3 - 6 } & annual herbs & 781 & 14.8 & 26.4 & $58-67$ \\
\cline { 3 - 6 } & cereals & 738 & 12.9 & 23.0 & $96-110$ \\
\hline \multirow{3}{*}{4.} & \multirow{2}{*}{ Tyumenskaya 25 } & green manure & 791 & 16.5 & 28.5 & $54-71$ \\
\cline { 3 - 7 } & annual herbs & 783 & 14.9 & 26.8 & $48-64$ \\
\cline { 3 - 7 } & cereals & 745 & 13.0 & 24.2 & $93-107$ \\
\hline $\mathrm{HCP}_{05}$ green manure & 17 & 1.2 & 1.8 & - \\
\hline $\mathrm{HCP}_{05}$ annual herbs & 21 & 0.9 & 2.3 & - \\
\hline $\mathrm{HCP}_{05}$ cereals & 13 & 1.4 & 1.6 & - \\
\hline
\end{tabular}

From the data shown in Table 1, it can be seen that the studied wheat varieties, including the standard, gave green manure fallow and annual grasses, according to their predecessors, grain suitable for food purposes. For the grain predecessor, all indicators are declining. The exception was the varieties Novosibirskaya 31, Omskya 36 and Tyumenskaya 25, in which one indicator the gluten content remained at an average level.

In the experiment with the sowing dates, the studied wheat varieties behaved differently (Fig. 2). So, for the Novosibirskaya 31 variety, the first sowing period was the best, for the rest - the second. On the third sowing period, the Iren variety reacted positively, the rest of the varieties gave yields below the first and second sowing dates.

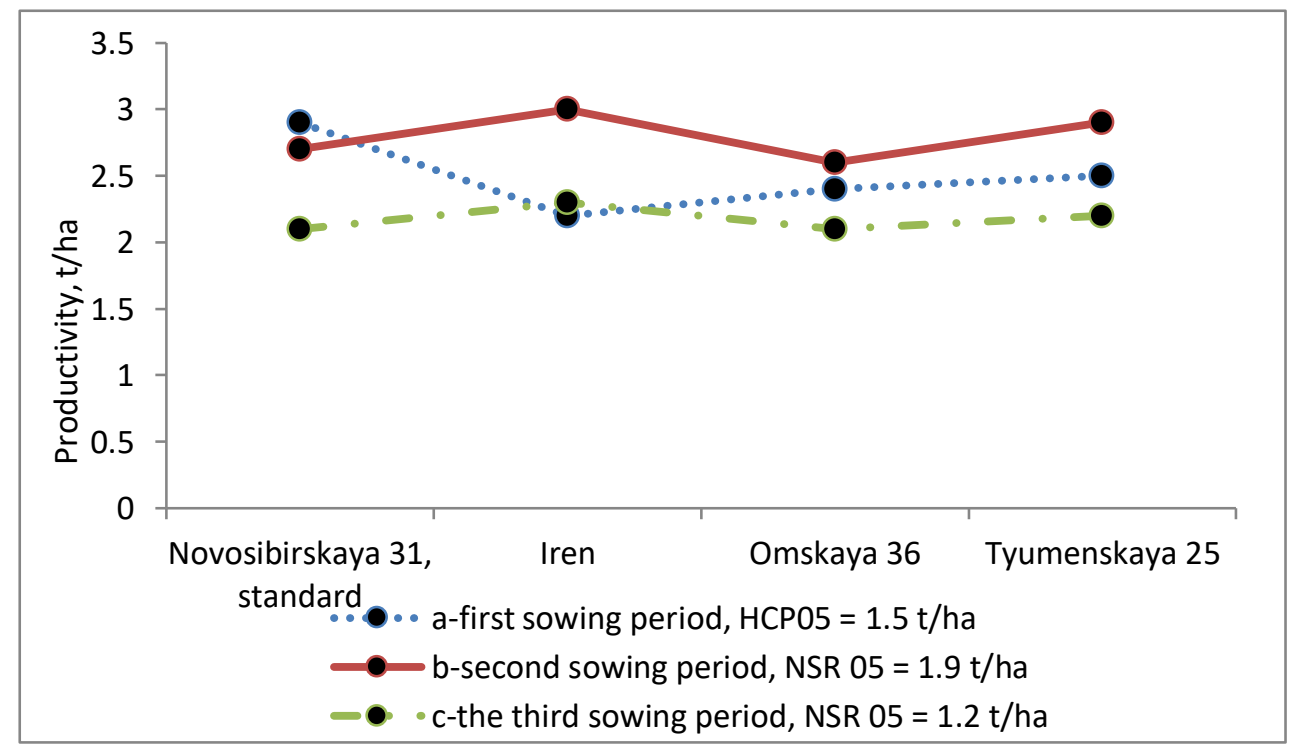

Fiq. 2. Productivity of wheat varieties depending on the sowing period, 2016-2018 (predecessor of annual grasses)

Sowing timing influenced the grain quality of wheat varieties (table 2).

Table 2. Influence of sowing time on grain quality of wheat varieties, 2016-2018 (predecessor of annual grasses)

\begin{tabular}{|c|c|c|c|c|c|c|}
\hline \multirow[b]{2}{*}{ № } & \multirow{2}{*}{ Variety } & \multirow{2}{*}{$\begin{array}{c}\text { Sowing } \\
\text { time }\end{array}$} & \multirow{2}{*}{$\begin{array}{l}\text { Volumetric } \\
\text { weight of } \\
\text { grain, g/l }\end{array}$} & \multicolumn{2}{|c|}{ Content, \% } & \multirow{2}{*}{$\begin{array}{c}\text { Gluten } \\
\text { quality, units } \\
\text { IDK-1 }\end{array}$} \\
\hline & & & & protein & gluten free & \\
\hline 1. & & first & 780 & 15.6 & 28.2 & $49-71$ \\
\hline
\end{tabular}




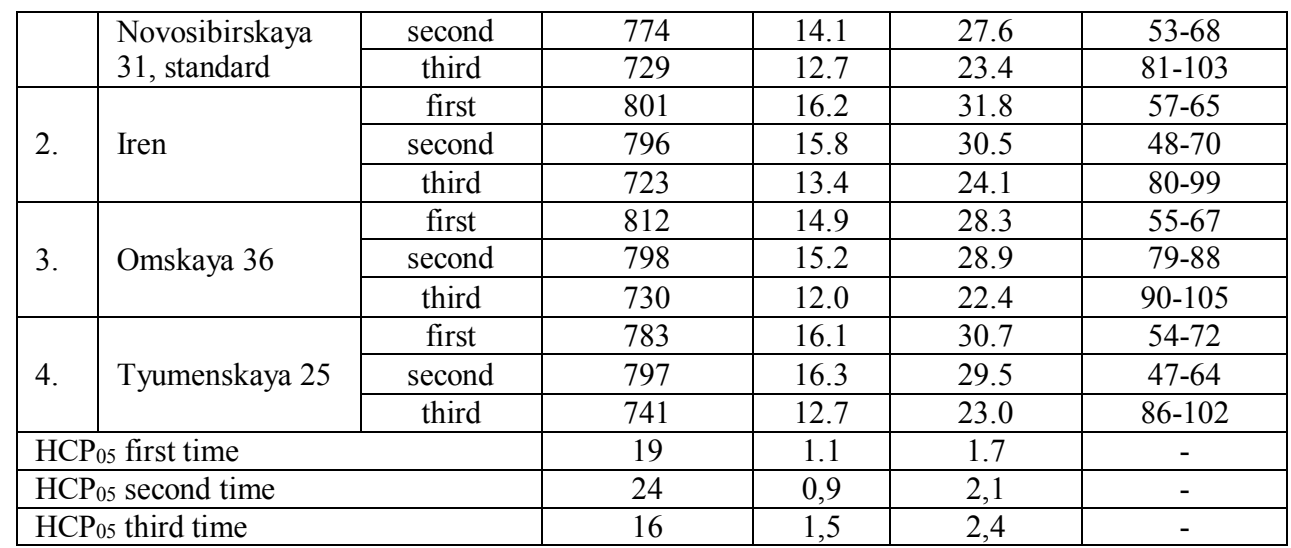

From the analysis of the data in Table 2, it follows that in the conditions of the northern forest-steppe of the Tyumen region with its short summer, even early ripening varieties of wheat sharply reduced the indicators of grain quality during the third sowing period. At the same time, the grain did not meet the requirements of GOST for food wheat.

In an experiment with different levels of mineral nutrition, it was found that varieties Novosibirskaya 31 and Iren are more responsive to high doses of fertilizers (Fig. 3). These varieties are suitable for cultivation in farms with an average and high level of farming culture, while the varieties Omskaya 36 and Tyumenskaya 25 are more suitable for farms with an average level of farming culture.

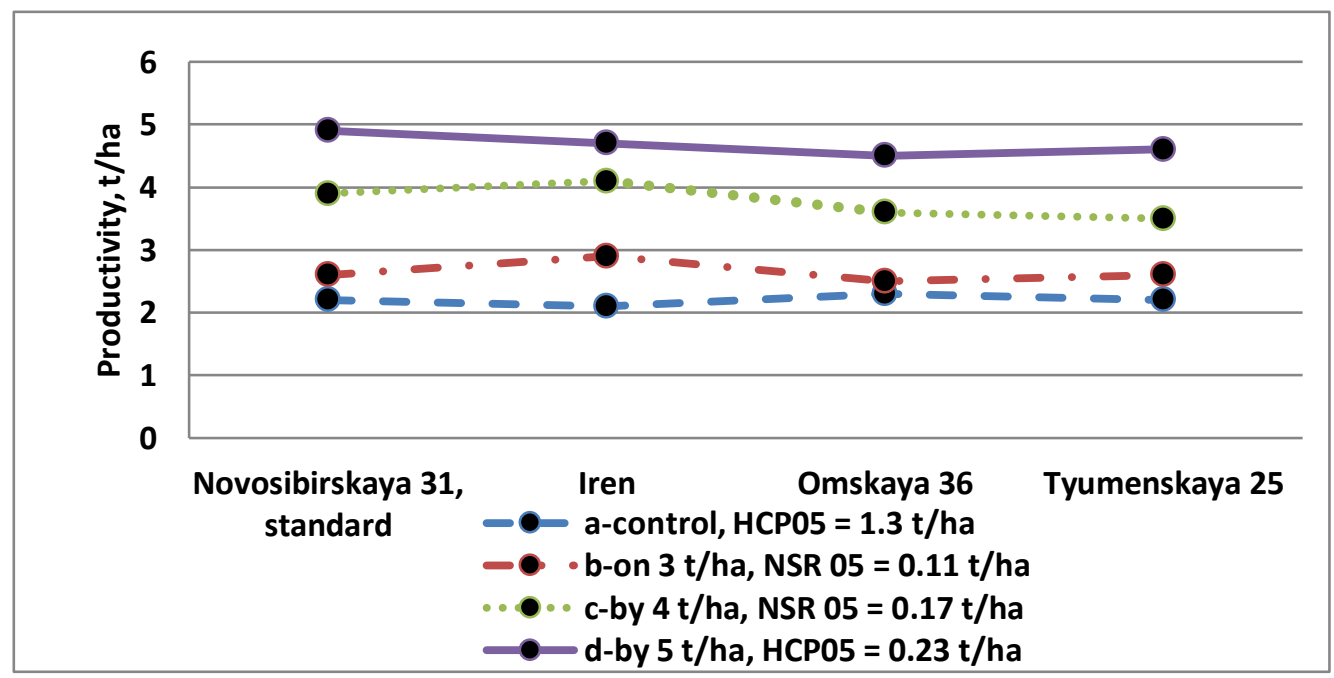

Fiq. 3. Productivity of wheat varieties depending on the level of mineral nutrition, 2016-2018 (predecessor of annual grasses)

Varieties Irene, Omskaya 36 and Tyumenskaya 25 had high indicators of grain volumetric weight, protein and gluten content, as well as its quality up to a yield level of $4 \mathrm{t} / \mathrm{ha}$. Further, all indicators decreased. The exception was the Novosibirskaya 31 variety, in which the noted grain quality indicators remained up to the yield level close to $5 \mathrm{t} / \mathrm{ha}$.

\section{Conclusion}


1. In the crop rotation of farms in the forest-steppe zone of the Tyumen region, it is necessary to increase the share of green manure fallows to $15-20 \%$.

2. Of the registered early ripening wheat varieties, Novosibirskaya 31 and Iren 'sorts have an advantage over Omskaya 36 and Tyumenskaya 25 in terms of yield and grain quality over the predecessors green manure fallow and annual grasses.

3. Varieties Iren, Omskaya36, Tyumenskaya 25 increase the quality of grain to a yield level of 4 t/ha, and variety Novosibirskaya 31 - to a yield level close to $5 \mathrm{t} / \mathrm{ha}$. Consequently, this variety is suitable for cultivation on farms with a high level of farming culture.

4. At the third sowing date, the studied wheat varieties reduced the yield and grain quality. It did not meet the requirements for food wheat. The exception in terms of yield was the Iren variety, its yield was higher compared to the first sowing period, but the quality of the grain was much lower.

\section{References}

1. D.I. Eremin, Eurasian soil science 49(5), 538-545 (2016) DOI: 10.1134/S1064229316050033

2. Y.P. Loginov, A.A. Kazak, L.I. Yakubyshina, Annals of Agri Bio Research 24, 76-81 (2019) DOI: 2-s2.0-85071655469

3. A.A. Kazak, Y.P. Loginov, Annals of Agri Bio Research 24, 174-182 (2019) DOI: 2-s2.08507612158

4. A.A. Kazak, Y.P. Loginov, D.I. Eremin, Agricultural Science Euro-North-East. 20(3), 219229 (2019) https://doi.org/10.30766/2072-9081.2019.20.3.219-229

5. Y. Kazak, D. Loginov, S. Eremin, A. Yashchenko, A. Gaizatulin, Amazonia Investiga 9(25), 143-152 (2020) DOI: 10.34069/AI/2020.29.05.15

6. O.V. Shulepova, I.V. Opanasyuk, R.I. Belkina, Plant Cell Biotechnology and Molecular Biology 21, 181-192 (2020) DOI: 2-s2.0-85099661564

7. A.V. Lyubimova, G.V. Tobolova, D.I. Eremin, I.G. Loskutov, Vavilovskii Zhurnal Genetiki i Selektsii 24(2), 123-130 (2020) DOI: 10.18699/VJ20.607

8. R. I. Belkina, A. Y. Pershakov, V. M. Gubanova, Plant Science Today 8(1), 1-7 (2021) https://doi.org/10.14719/pst.2021.8.1.943

9. L. Yakubyshina, O. Shakhova E3S Web of conferences, Energy Management of Municipal Facilities and Environmental Technologies, EMMFT2020, 1049-1054 (2020)

10. R. I. Belkina, A. Y. Pershakov, V. M. Gubanova. Plant Science Today 8(1), 1-7 (2021) https://doi.org/10.14719/pst.2021.8.1.943

11. R.I. Belkina, Yu.A. Letyago, D.I. Kucherov IOP Conference Series: Earth and Environmental Science 624(1), 012169 (2021) DOI: 10.1088/1755-1315/624/1/012169

12. V. Iglovikov, Procedia Engineering 165, 800-805 (2019) DOI: 10.1016/j.proeng.2016.11.778

13. G.M. Gilmanova, Procedia Engineering 165, 794-799 (2019) DOI: 10.1016/j.proeng.2016.11.777

14. D. I. Eremin, D. V. Eremina, MATEC Web Conf, 106 (2017) org/ DOI: $10.1051 /$ matecconf $/ 201710601044$

15. N.V. Abramov, S.A. Semizorov, S.V. Sherstobitov, M.V. Gunger, D.A. Petukhov, International Conference on Agribusiness, Environmental Engineering and Biotechnologies, AGRITECH-III 2020; Krasnoyarsk; Russian Federation (2020) DOI: 10.1088/1755-1315/548/3/032002

16. Iglovikov, International Scientific Conference on Biotechnology and Food Technology, BFT 2020; Saint Petersburg; Russian Federation (2020) DOI: 10.1051/e3sconf/202021503006 
17. V. Morgunov, J. Pozherukova, E. Kolmer, A. Gultyaeva, V. Abugalieva and etc. 216(11), 170 (2020) DOI: 10.1007/s10681-020-02701-y

18. I.E. Likhenko, A.F. Zyryanova, N.I. Likhenko, E.A. Salina, A.I. Stasyuk, A.B. Shcherban', Russian Journal of Genetics: Applied Research 5(3), 198-207 (2015) DOI: $10.1134 /$ S2079059715030107 